\title{
Nutrient management in Hungary - A review -
}

\author{
J. LOCH \\ Institute of Agrochemistry and Soil Science, University of Debrecen
}

\section{Introduction}

Due to its function as the basis for agricultural production, soil is one of the most precious natural assets in Hungary. Taking the opportunity offered by the International Year of Soils, an overview is given here of the national potential in Hungary, including the trends in soil nutrient management in recent decades. The overall objective of agricultural production has always been to satisfy the requirements of the population. The approaches, in terms of the intensity and method of production, have changed over time, from an initial concentration on quantity to the more recent emphasis on quality. Cost efficiency and sustainability are the biggest challenges now facing the farming community. The main prerequisite for sustainability in agriculture is the preservation of soil fertility. It is generally accepted that the preservation of the soil must be achieved without any unnecessary pressure on the environment, which requires the application of environmentally sound farming practices. The intensity of production must be harmonized with economic aspects, and the management of soil nutrients must be specifically designed for the site in question.

VÁRALLYAY and NÉMETH (1996) underlined the fact that the importance of individual soil functions changes over time. Thus, while acknowledging the primary importance of fertility, which determines the biomass yield, other aspects of the soil, such as its water- and nutrient-storing capacity, and its filtering and detoxifying functions must also be preserved if the requirements of sustainable farming are to be met.

It is worth noting that Liebig mentioned the necessity of achieving sustainability in farming as early as 1860 , noting that soil fertility had always been something that could keep societies together or disrupt them, that could cause nations and states to collapse or to become glorious. He also noted that it was the maintenance of soil fertility, and not just maximum yields that the farmer should strive to achieve. (Quoted by BERGMANN, 1970). 
In 1962, BERGMAN wrote that the fertility of agricultural soils not only gave a true picture of individual production units, but also mirrored human activities that affected the soil in either positive or negative ways.

In the broad sense, the maintenance or improvement of soil fertility or its reduction or destruction, for instance by polluting it with heavy metals or other contaminants, was equivalent to the maintenance or destruction of life itself.

The scientific credo of BERGMAN (1963) was well expressed by his conviction that we should work at all times to ensure a peaceful future and the victory of mankind over starvation, poverty and diseases, aiming to make the world a better place to live in.

When analysing the tasks facing agricultural chemistry, LINSER (1975) was critical about the responsibilities of scientists as regards issues of crop production and the protection of the environment, warning them to distance themselves from extreme views, and suggesting that when the environment appears to be in danger, we tend to question the sense and legitimacy of any human interference at all.

\section{The early years of nutrient management in Hungary}

In the years after the abolition of serfdom, land-owners faced the problem of soil nutrient deficiency, combined with the lack of capital. This meant that fallow lands were maintained as a necessary evil, as a cloak for weak manure potential (KENESSEY, 1858).

The introduction of up-to-date technologies was only possible on large estates that had a solid capital background. Almost everyone - landlord and peasant - was well aware of the right direction to take. Yet the practical difficulties that arose, such as the scarcity of farmyard manure, the lack of labourers, the remains of the crop-and-fallow system, and the consequent delay in the introduction of crop rotation systems, did not allow good theory to overcome bad practice (GAÁL, 1978).

Nevertheless, this was the age when the necessity for soil fertilization was first advocated. GALGÓCZY (1854) was of the opinion that the land would never get exhausted if the farmer did not tire of cultivating it properly and supplying it with the necessary quantity of nutrients. He was convinced that the grounding of sound farming lay in manure and fertilization.

At this time, the generally accepted principle was that more animals meant more manure, which in turn meant higher yields. The role of mineral fertilizers became commonly known after the middle of the $19^{\text {th }}$ century thanks to the efforts of Boussingault, Liebig and Sprengel. Liebig and Sprengel proved that the nutrients contained in farmyard manure could be substituted by industrial fertilizers. Thanks to their efforts, the production and use of chemical fertilizers, and the resultant significant yield improvement had begun in Western Europe well before this was possible in Hungary.

The introduction of chemical fertilizers in Hungary did not start until after the 1899/1900 Millenneum, but the quantities used in the decades up to World War II amounted to only a few $\mathrm{kg} \cdot \mathrm{ha}^{-1}$ of nitrogen, phosphorus and potassium. 


\section{The development of nutrient management between 1965 and} 1990

The turning point that resulted in radical changes took place in 1960 . Bocz (1962) pointed out that under the favourable ecological conditions in Hungary, the rational addition of nutrients to the soil could make stagnating yields rise. As in earlier years, organic manure was scarce at this time. The quantity of manure produced by livestock was unable to satisfy the soil nutrientrequirements of crop production.

To overcome this problem, Láng G., Bocz E., Győrffy B., and Sarkadi J. elaborated a schedule of chemical fertilization for use in crop production. Their efforts led to a dynamic growth in fertilizer application, and this, together with the introduction of new cultivars and hybrids in wheat and maize production, resulted in a spectacular increase in yields.

Four phases can be differentiated in the development of fertilizer use in Hungary in terms of yield averages:

- $\quad$ Before 1960 less than $30 \mathrm{~kg} \cdot \mathrm{ha}^{-1}\left(\mathrm{~N}+\mathrm{P}_{2} \mathrm{O}_{5}+\mathrm{K}_{2} \mathrm{O}\right)$ was applied;

- Between 1960 and 1975 this increased nearly tenfold to $275 \mathrm{~kg} \cdot \mathrm{ha}^{-1}$;

- In the years 1975-1985 the figures remained nearly the same;

- After 1985 fertilizer use showed a moderate decrease, followed by a drastic drop from 1990 onwards.

The first phase was characterized by low levels of fertilizer application and relatively low yields. In the second phase, application rates gradually approached the level in Western European countries with a long history of fertilizer application. During this phase, there was a 2.5 times increase in the yields of wheat and maize. Yields remained high in the third phase, but they began to decrease in the fourth phase, when the use of fertilizers fell back to the level of the 1960s.

The increase in chemical fertilizer utilization was accompanied by a gradual decrease in the nutrient doses applied to the soil in the form of organic manure dropped to around $15 \%$ of the total by 1975 . Due to the reduction in the number of livestock, the average domestic output of $3 \mathrm{t} \cdot \mathrm{ha}^{-1}$ of organic manure fell to about $50 \%$ after 1990 .

The doubling of the yields could be attributed to the introduction of the highyielding cultivars and to the use of improved technologies. Improvements infertilization, chemical pest and disease control, and soil cultivation and irrigation all had a share in improving yields, but the contribution of fertilization was the greatest. In the years 1960-1985, the average fertilizer use in Hungary reached the level applied in developed Western countries, and this was backed up by improved technologies. By the middle of the 1970s the national nutrient balance had become positive (Debreczeni, Kádár and Sarkadi). The earlier soil-depleting fertilization practices were replaced by soil-enriching technologies (KÁDÁR, 1999). For a comprehensive review of the history of Hungarian agricultural nutrient management, see KovÁCS and CSATHÓ (2005). 
The use of fertilizers declined moderately between 1985 and 1990, followed by a dramatic drop to the level of the 1960s, resulting in a decrease in the yield averages of wheat and maize. This sudden reduction in fertilizer use can be attributed to the break-up of the large state farms, to the increasing cost of fertilization, and to the lack of capital available to farmers.

\section{Nutrient management after 1990}

Fertilizer use slowly increased after 1995, with $\mathrm{N}$ applications as high as 60-70 $\mathrm{kg} \cdot \mathrm{ha}^{-1}$, while $\mathrm{P}$ and $\mathrm{K}$ utilization, which was previously very low, was doubled and reached $60-70 \mathrm{~kg} \cdot$ ha $^{-1}$ (Fig. 1).

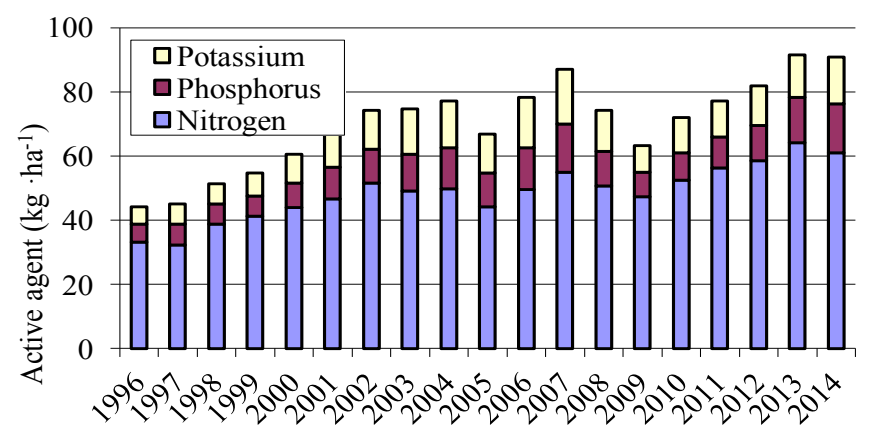

Fig. 1

Use of $\mathrm{N}, \mathrm{P}_{2} \mathrm{O}_{5}$ and $\mathrm{K}_{2} \mathrm{O}$ fertilizers $\mathrm{kg} \cdot \mathrm{ha}^{-1}$ on agricultural land

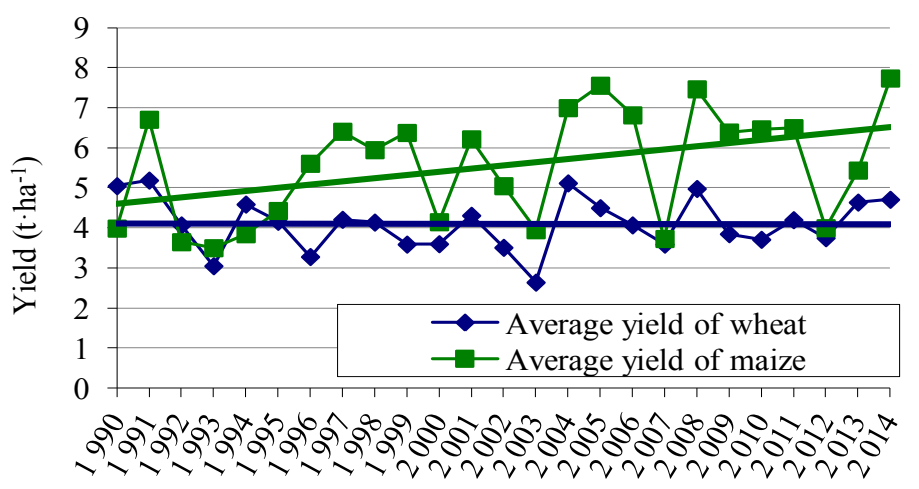

Fig. 2

National yield averages of wheat and maize $\left(\mathrm{t} \cdot \mathrm{ha}^{-1}\right)$ 
The gradual increase in fertilizer application resulted in a subsequent rise in maize yield averages and, except in droughty years, the earlier average of $6 \mathrm{t} \cdot \mathrm{ha}^{-1}$ has been regained or even exceeded By contrast, the average yields of wheat have stagnated, never rising higher than the average of $5 \mathrm{t} \cdot \mathrm{ha}^{-1}$ reached under intensive fertilization (Fig. 2). The differences between wheat and maize yields can be attributed to a variety of causes. The primary reason is that wheat is more sensitive to nutrient deficiencies, whereas maize is more sensitive to water deficiency. Another important difference is that maize production takes place, for the most part, in production systems that use certified seeds and apply balanced nutrient supplementation regimes, which is not always the case with wheat production. The fluctuations in the yields of both crops are an indication that the crop water requirements need to be carefully estimated every year.

\section{The nutrient supply of soils}

The primary indicator of soil fertility is the supply of nutrients available to the plants. The triennial sampling and testing of cropped arable lands was introduced in Hungary in 1970. The laboratory tests assessed the basic physical and chemical parameters of the soils, and the readily available forms of macro- and microelements. The fact that the nutrient supply of Hungarian soils improved and yields increased in years with more intensive fertilizer use can largely be attributed to this regular testing, associated with expert advice.

In years when increasing quantities of fertilizers were applied, the nutrientsupplying capacity of the soils rose, falling again when less fertilizer was used (PÁlmai \& Horváth, 1998; KÁdÁR, 1999; LOCH, 1999). PÁlmai and HorvátH (1998) found that lower fertilizer doses caused the nutrient- supplying capacity of regularly tested plots to drop by an average of one category. The Soil Protection Act (1994) makes it mandatory for farmers to monitor and maintain the fertility of their land and to base nutrient management schemes on soil tests, which is also a precondition for obtaining EU funds. Thanks to this, the regular testing of arable lands has become common practice.

\section{The pH of the soils}

The use of sustainable farming technologies, the better availability of soil nutrients, more intensive soil life and the prevention of toxic element mobility are equally important objectives if the $\mathrm{pH}$ of acid soils is to be corrected.

Acidity is a genetically determined property of brown forest soils, grassland soils and some alluvial soils, but the application of fertilizers, especially that of ammonium nitrate and urea may cause acidity to increase in all carbonate-free soils with low buffering capacity. According to earlier data from the soil monitoring system, some $50 \%$ of Hungarian soils are acid, and most require amelioration due to their high hydrolytic acidity levels. The application of chemical soil amendments is highly recommended in $15 \%$ of sample areas, and recommended in $20 \%$. 
When evaluating the data of the 1 st and 3rd cycles of national soil testing, BUZÁSNÉ et al. (1986) found that the proportion of soils with acidity lower than $\mathrm{pH}(\mathrm{KCl}) 6.0$ grew by $7 \%$ nationwide, predominantly at the expense of areas with a $\mathrm{pH}(\mathrm{KCl})$ of over 7.0. The proportion of soils with acidity higher than $\mathrm{pH}(\mathrm{KCl}) 5.5$ increased by $6 \%$. In most cases acidification occurs as a consequence of intensive fertilizer application on soils deficient in colloids and with low buffering capacity. These data draw attention to the importance of calcium supplementation and chemical soil amelioration in correcting the malpractices of the past (LOCH, 2006a).

\section{Toxic elements}

The conclusions drawn at consultative meetings in the framework of cooperation between Central and Eastern European countries reinforced the opinion that the methods and limit values used for the analysis of toxic elements and organic pollutants in Hungary comply with the requirements of the EU. The results of soil monitoring tests show that the toxic element content was below the limit values in $95 \%$ of the samples tested in Hungary. Cropped arable lands are not polluted, and toxicity exceeding the limit values is only measured locally, in the vicinity of industrial sites (BUZÁSNÉ \& LOCH, 2000).

The implementation of the Soil Conservation and Information Monitoring System in Hungary in 1992 was an important achievement in assessing the condition of the soils. The cyclical testing of soil nutrients and other soil properties, which was first implemented in Hungary among the European countries, facilitated the monitoring of trends at national level. Tests carried out in sample plots, however, do not obviate the need to carry out field-size measurements aimed at establishing sitespecific nutrient management schemes.

\section{Fertilization recommendations}

The method of fertilization elaborated at the Centre of Plant Protection and Agro-chemistry, Ministry of Agriculture and Food (MÉM-NAK) is based on the regular nationwide soil testing system and was introduced with the authorization of the Ministry (ANTAL et al., 1979; BuZÁs et al., 1979). Thanks to regular soil tests and subsequent expert recommendations, both the utilization of fertilizers and yields began to increase. Much of the criticism later directed at this method was roused by the modification of the supply limit values in 1987, which was blamed for the excessive application of fertilizers. Meanwhile, several new consulting methods were developed, the most widely known being the New Environmentally Sound and Cost-efficient Recommendation System in Fertilization elaborated jointly by scientists from the Research Institute for Soil Science and Agricultural Chemistry and the Agricultural Research Institute (CSATHÓ et al., 1998, 2003).

Like earlier fertilization recommendation systems in Hungary, this was also based on the nutrient balance. Its primary advantage is that it offers the farmers a 
choice of four different fertilization options. Levels A (minimum) and B (environmentally sound) are recommended for use in environmentally sensitive areas and are designed to ensure a cost-efficient, $95 \%$ yield average by providing and maintaining a medium level of PK supplies. Versions C (balance-based) and D (integrated) aim to provide maximum yields via moderately intensive fertilizer use in soils with no environmental sensitivity. All the dose recommendations are below those recommended by the MÉM-NAK method.

A survey carried out in cooperation with other Central and Eastern European countries provided a comparative analysis of the recommendation methods applied in ten countries using samples of the same types of soil. Each country used their own nutrient testing methods and recommendation systems to estimate the NPK doses required to ensure given yield averages for wheat, maize and potatoes. The results showed that recommendations based on the MÉM-NAK system were close to the average of the values recommended by the ten countries.

\section{The conservation of soil fertility and the protection of the environment}

Education, research and fertilizer recommendations all have significant roles in harmonizing farming and environmental concerns. The young generation must be equipped with state-of-the-art knowledge on agricultural chemistry and soil science. The primary issues facing research are the all-round assessment of the impact of fertilizers and improvement in research methods and recommendations. A National Agro-environmental Programme was set up in Hungary to ensure the development and dissemination of farming methods that take into consideration the need to protect and improve the environment, nature, rural regions and natural resources (ANONYMOUS, 1999). One important achievement of the programme is the classification of areas based on their environmental sensitivity. This could promote the rational use of fertilizers, with special regard to the application of nitrogenous fertilizers.

The $\mathrm{N}$ recommendation method currently used, based on soil humus content, should be replaced by a method based on the measurement of inorganic $\mathrm{N}$ forms. The fractions of readily soluble and mobilizable organic $\mathrm{N}$ in the soil should also be assessed, preferably based on the $\mathrm{N}$ content soluble in $0.01 \mathrm{M}$ calcium chloride (HouBA et al., 1990). It has been shown (LoCH, 2006b) that the inorganic $\mathrm{N}$ fraction and the readily available soluble organic $\mathrm{N}$ fraction make up some $30-40 \%$ of the soluble $\mathrm{N}$ content, an amount high enough to be taken into consideration when plant nutrition and environmental objectives are concerned. The definition of optimum $\mathrm{N}$ doses is also important due to their impact on surface and ground waters. The use of novel alternative nutrient sources such as food composts should also be monitored more efficiently, and strict regulations for their application should be elaborated, similar to those imposed for sewage sludge and plant composts. 


\section{Weather extremes}

The incidence of extreme weather events have increased in recent years. The frequency with which droughts and floods occur makes it imperative to find solutions to the problems facing agricultural water management. More efficient agriculture will require more comprehensive water management and improvements in irrigation potential. The water supply is one of the cardinal factors in crop production. The Committee for Soil Science, Water Management and Crop Production of the Hungarian Academy of Science recently issued a statement that made the following points:

- Water plays a decisive and integrating role in Hungarian crop production;

- There is a need to develop complex water-, energy- and environment friendly technologies that take the specific features of growing sites and cultivars into consideration. Among the elements in these technologies, rational nutrient management is of outstanding importance. A state-of-the-art technology for optimum water supplementation, providing better specific water utilization, should help to improve the drought tolerance of plant species and cultivars.

The points in this statement are consistent with each other and with the objectives set out in this paper.

\section{Summary}

Soil, the basis for agricultural production, is one of the most precious natural assets in Hungary. The paper gives a brief overview of the past and present states of nutrient management. Crop production has at all times been driven by the food requirements of the population, the aim being to satisfy these needs using different methods and different intensities, in order to achieve high yields and, in more recent times, high quality.

The primary responsibilty of nutrient management today is to harmonize the preservation of soil fertility with farming objectives and environmental concerns. The quantities of organic manure produced by livestock in Hungary are insufficient to satisfy crop requirements. Consequently, in the decades after the Second World War, experts elaborated a scheme for the utilization of inorganic fertilizers. Over the period 1960-1985, fertilizer use rose almost tenfold from a total of $30 \mathrm{~kg} \cdot \mathrm{ha}^{-1}$ $\left(\mathrm{N}+\mathrm{P}_{2} \mathrm{O}_{5}+\mathrm{K}_{2} \mathrm{O}\right)$ to $285 \mathrm{~kg} \cdot \mathrm{ha}^{-1}$. The national nutrient balance became positive in 1970. The earlier practice of soil-depleting nutrient management was replaced by soil-enriching fertilization, resulting in improved soil nutrient supplies and the doubling of wheat and maize yields.

The drastic decline in fertilizer application at the turn of the century led to lower wheat and maize yields. As a consequence of the negative nutrient balance, the nutrient-supplying capacity of the soils also decreased. After reaching a low point in 1995 , fertilizer utilization began to rise again and maize yields reached the earlier average of $6 \mathrm{t} \cdot \mathrm{h}^{-1}$, except in droughty years. Wheat yields, however, remained be- 
low those achieved in earlier years. This can probably be attributed to insufficient attention to growing conditions and the inappropriate use of seed and nutrients.

Education, research and fertilization recommendations will face new challenges in the harmonization of crop production requirements with environmental concerns. To comply with national and EU regulations, it will be imperative to continue the regular testing of arable lands used for crop production.

When measuring the $\mathrm{N}$-supplying capacity of the soil, the analysis of humus content should be replaced by the analysis of inorganic $\mathrm{N}$ forms and mobilizable $\mathrm{N}$ supplies, for which the assessment of the $\mathrm{N}$ fraction soluble in $0.01 \mathrm{M}$ calcium chloride is recommended. The definition and application of optimum $\mathrm{N}$ doses is important for the protection of both surface and ground waters.

If the fertility of the soils is to be maintained, it is necessary to correct the $\mathrm{pH}$ of acidic soils and to supplement the soil calcium content to compensate for the acidification caused by fertilization. This is the only way to ensure the better utilization of nutrients, more active soil life and the prevention of toxic element mobility.

The New Environmentally Sound and Cost-efficient Recommendation System in Fertilization elaborated by the Research Institute for Soil Science and Agricultural Chemistry and the Agricultural Research Institute is one of the novel recommendation systems available for fertilizer use. The primary achievement of this system is that it differentiates between recommendations for environmentally sensitive and less sensitive soils. It is clear that the various advisory systems need to be harmonized in the future and that the recommendations should be tested regularly in field trials to adapt them to changing conditions. Further research is also needed to ensure the safe utilization of alternative nutrient sources, such as the growing reserves of industrial by-products and food composts.

The increasingly frequent occurrence of droughts and other extreme weather events will require more circumspect, comprehensive water management and improvements in irrigation systems. Optimum nutrient and water supplies are the corner-stones of crop production.

Keywords: nutrient management, soil fertility, sustainability, environment

\section{References}

ANONYMous 1999. National Agro-environment Programme. Ministry of Agriculture and Rural Development. Budapest.

Antal, J., Buzás, I., Debreczeni, B., Nagy, M., Sipos, S., \& Sváb, J., 1979. Guidelines of N, P, K Application. In: Guidelines of Fertilization on Large-size Farms Part I. (In Hungarian). (Eds.: BuZÁs, I., FeKETE, A., BuZÁs, I.-NÉ, CSENGERI, P.-NÉ, \& KovÁcs Á.-NÉ) 1-47. MÉM Növényvédelmi és Agrokémiai Központ. Budapest. Bergmann, W., 1962. Gesunder Boden - Gesunde Pflanzen - Gesunde Tiere und Menschen. In: Gedanken, Zitate und Aphorismen. Agroplant.

BERGMANN, W., 1970. Welternährungslage und Nahrungsmittelproduktion. Urania Bezirksvorstand. Gera. 1-24. 
Bocz, E., 1962. Preliminary Assessment of the 20-year Plant Production Program with a view to Progress towards the Achievement of the Objectives (In Hungarian). Készült az Országos Távlati Tudományos Tervkészítő Bizottság keretében, az Országos Tervhivatal megbízásából. (Manuscript)

BuzÁs, I., EleK, É., Nyíri, L., Loch, J., KereszTÉNY, B. \& Kotz T., 1979. Guidelines for $\mathrm{Ca}, \mathrm{Mg}$ and Microelement Application (In Hungarian). In: Guidelines for Fertilization on Large-size Farms. Part II. (Eds.: BuZÁs, I., FeKETE, A., BuZÁs I..NÉ, CSENGERI, P.-NÉ \& KovÁCs Á.-NÉ) 48-66. MÉM Növényvédelmi és Agrokémiai Központ. Budapest. BuzÁs, I.-NÉ., CSERnÁtony, C.-NÉ \& HerczeG, A. (1986):The reduction of soil pH in Hungary. Agrochemistry and Soil Science. 35. 63-71.

BuZÁSNÉ, M.H. \& LOCH, J., 2000. Das Bodenmonitoring System Ungarns: Toxische Elemente und Schadstoffe. VDLUFA Schriftenreihe 54/2000. 41-51.

CSATHÓ, P., ÁRENDÁS, T. \& NÉMETH, T., 1998. New, environmentally friendly fertilizer recommendation system based on the data set of the Hungarian long term field trials set up between 1960 and 1995. Commun. Soil Sci. Plant Anal. 29. 2161-2174.

CSATHÓ,P., ÁRENDÁs,T. \& NÉMETH, T., 2003. New, Environmentally Friendly Fertilizer Recommendation System in Support of Improved Maize Production (In Hungarian). In: Fifty Years of Hungarian Maize Production. (Eds.: MARTON, L. C. \& ÁRENDÁs, T.) 99-104. MTA Mezőgazdasági Kutatóintézet. Martonvásár.

GAÁL, L.1978. Hungarian Plant Production - A Retrospective Overview (In Hungarian). Akadémiai Kiadó. Budapest.

GALGÓCZY, K., 1854. The Field Farmer (In Hungarian). Pest. Heckenast. 29.

Houba, V. J. G., Novozamsky, I., Lexmond, T. M. \& VAN Der Lee J. J., 1990. Applicability of $0.01 \mathrm{M} \mathrm{CaCl}_{2}$ as a single extraction solution for the assessment of the nutrient status of soils and other diagnostic purposes. Commun. Soil Sci. Plant Anal. 21. 2281-2290.

KÁDÁR, I., 1999. Nutrient Management in Hungary at the Millennia (In Hungarian). Agrochemistry and Soil Science. 48. (1-2) 193-216.

KovÁCS, G. \& CsATHÓ, P. (Eds.), 2005. The Nutrient Balance of Hungarian Agriculture 1901-2003 (In Hungarian). MTA TAKI. Budapest.

Kenessey, K., 1858. Golden Rules for the Farmer (In Hungarian). Pest, Hercz.

LINSER, H., 1975. 50 Jahre Bundesversuchsanstalt Linz. Jahrbuch.

LOCH, J., 1999. Topical questions in nutrient management in Hungary (In Hungarian). Tiszántúl Agricultural Science Meeting, Agricultural Chemistry and Soil Science Section, 28-29 October 1999. Conference Proceedings. 11-18. University of Agricultural Sciences. Debrecen.

LocH, J., 2006a. The Role and Importance of Soil Tests in Nutrient Management and Environmental Protection (In Hungarian). Agrártudományi Közlemények. Acta Agraria Debreceniensis. 19. 3-8.

Loch, J., 2006b. Assessment of soil tests. In: The Application of Soil Testing Methods in Support of Improved Nutrient Management in the Sandy Soils of Nyírség (In Hungarian). (Eds.: Loch J. \& LAZÁNYI J.) 51-77. Westsik Vilmos Nyírségi Tájfejlesztési Alapítvány. Nyíregyháza.

VÁRAllyay, G. \& NÉmeth, T., 1996. Basics of Sustainable Farming: Soil Science and Agrochemistry (In Hungarian). In: MTA Agrártudományok Osztályának tájékoztatója. 80-92. 